\title{
Effect of Al203 Coatings on Microstructural and Optoelectronic Properties of Porous Si/ SnO2 Composites.
}

mondher ghrib ( $\nabla$ mondher.ghrib@yahoo.fr)

Carthage High School

\section{Basma GHRIB}

Université de Sfax: Universite de Sfax

\section{Sonia Sonia Ben Slama}

Technopole de Borj Cédria: Technopole de Borj-Cedria

\section{Wisem Dimassi}

Borj Cedria Science and Technology Park: Technopole de Borj-Cedria

Mounir Gaidi

Borj Cedria Science and Technology Park: Technopole de Borj-Cedria

\section{Rachid Ouertani}

Borj Cedria Science and Technology Park: Technopole de Borj-Cedria

\section{Hatem ezzaouia}

Borj Cedria Science and Technology Park: Technopole de Borj-Cedria

\section{Research Article}

Keywords: pSi/SnO2/Al2O3, Microstructure, Optical and electrical properties

Posted Date: July 7th, 2021

DOl: https://doi.org/10.21203/rs.3.rs-670960/v1

License: (c) (1) This work is licensed under a Creative Commons Attribution 4.0 International License. Read Full License 


\title{
Effect of $\mathrm{Al}_{2} \mathrm{O}_{3}$ coatings on microstructural and optoelectronic properties of
} porous $\mathrm{Si} / \mathrm{SnO}_{2}$ composites.

\author{
Mondher Ghrib ${ }^{1-2 *}$ Basma Ghrib ${ }^{3}$, Sonia Ben Slama ${ }^{2}$, Wisem Dimassi², \\ Mounir Gaidi ${ }^{4,5}$, Rachid Ouertani ${ }^{2}$, Hatem Ezzaouia ${ }^{2}$.
}

1. Higher Institute of Environmental Sciences and Technologies of Borj-Cédria (ISSTE)

2. Nanomaterials and Systems for Renewable Energies, Technopole de BorjCédria, BP 95, 2050 Hammam-Lif, Tunisia

3. University of Sfax-IPEIS, BP 1172-LaTICE Lab-ENSIT, 3018 Sfax, Tunisia

4. Centre for Advanced Materials Research, Research Institute of Sciences and Engineering, University of Sharjah, P. O. Box 27272 Sharjah, United Arab Emirates

*Corresponding author: E-mail addresses: mondher.gharib@isste.u-carthage.tn , mondher.ghrib@yahoo.fr

\begin{abstract}
:
In this work, $\mathrm{Al}_{2} \mathrm{O}_{3}$ coating effect on morphology, structure and optoelectronic properties of $\mathrm{Si} / \mathrm{SnO}_{2} / \mathrm{Al}_{2} \mathrm{O}_{3}$ porous matrix composites (PMCs) were investigated. A three-staked thin layers deposited on a $\langle 100\rangle$ oriented silicon substrate made these composites. First, porous silicon layers were achieved by electrochemical etching method. Then $\mathrm{Al}_{2} \mathrm{O}_{3}$ and $\mathrm{SnO}_{2}$ layers were successively deposited by physical and chemical vapor deposition, respectively. Morphological and micro-structural properties of the as prepared composites were evaluated by Scanning electron microscope, energy dispersive X-ray spectroscopy and X-ray diffraction. Results proved that $\mathrm{Al}_{2} \mathrm{O}_{3}$ concentration alters notably the porosity of the PMCs.Variable angle spectroscopic ellipsometry (SE) revealed a high correlation between the optical constants (n, k) and the PMC microstructure. Impedance spectroscopy revealed a semiconductor-metallic transition at high frequency in the temperature range between 340 to $410^{\circ} \mathrm{C}$.
\end{abstract}

Keywords: $\mathrm{pSi} / \mathrm{SnO}_{2} / \mathrm{Al}_{2} \mathrm{O}_{3}$, Microstructure, Optical and electrical properties

\section{Introduction}

Metal oxides include compounds like $\mathrm{TiO}_{2}, \mathrm{ZrO}_{2}, \mathrm{Cr}_{2} \mathrm{O}_{3}, \mathrm{SiO}_{2}, \mathrm{Al}_{2} \mathrm{O}_{3}$ and $\mathrm{SnO}_{2}$. Several compositions and properties of this family have been widely investigated for a 
wide range of industrial and technological applications [1-7]. They are used as insulators, semiconductors, conductors and superconductors. These binary oxides are currently being investigated as potential $\mathrm{SiO}_{2}$ substitutes in the next generations of semiconductor devices [1]. Among these materials, Tin oxide $\left(\mathrm{SnO}_{2}\right)$ thin films have been proved useful for a variety of applications including gas sensors, batteries, fuel cells, photovoltaic cells, photodetectors, transparent electronics, and thin film transistors (TFT) due to their excellent characteristics including chemical stability, high electrical conductivity and optical transparency. The properties of tin dioxide and alumina layers deposited on porous $\mathrm{Si}(\mathrm{pSi})$ depend on several factors such as the method of preparation, variety of phase states and degree of dispersity [8-12]. The $\mathrm{SnO}_{2}$ thin films are n-type semiconductors with direct optical band-gap of $3.9 \mathrm{eV}$ [13, 14]. Whereas $\mathrm{SnO}$ is a metastable material at room temperature and becomes more stable at higher temperatures. Various methods have been used to prepare $\mathrm{SnO}_{2}$ film such as electron beam evaporation, thermal evaporation of oxide powders, magnetron sputtering, spray deposition, chemical vapor deposition (CVD) [15-17] and sol-gel. In this work, two deposition techniques, physical vapor deposition (PVD) and CVD, were respectively used to deposit $\mathrm{Al}_{2} \mathrm{O}_{3}$ and $\mathrm{SnO}_{2}$ nano-crystals due to many advantages such as large production area and uniform distribution. Both techniques, metal oxide nanocrystals growth in the cavities of porous silicon permits an easy control of material compositions [18]. Appropriate porosity and high specific surface area of oxide supports are required for catalyst or ion exchange applications. In fact, ion exchange in the nanopores of the $\mathrm{Al}_{2} \mathrm{O}_{3} / \mathrm{SnO}_{2}$ binary system for the catalytic reaction is not widely recognized. Interestingly, the Alumina Tin oxide catalysts remains an urgent need to increase the catalytic activity and decrease the abrasive properties of the porous matrix composites (PMCs) as the average pore diameter of support materials corresponds to their particle size. Thus, the pore diameter is significant, as catalysts resist sintering highly particularly in the case of a metal catalyst [19]. Such properties encourage the use of Alumina Tin oxide as a tunnel barrier and dielectric gate [20-22]. Spectroscopic ellipsometry (SE) [23-24] is highly appropriate to analyze thin layers such as $\mathrm{pSi} / \mathrm{SnO}_{2} / \mathrm{Al}_{2} \mathrm{O}_{3}$. In this work, $\mathrm{pSi} / \mathrm{SnO}_{2} / \mathrm{Al}_{2} \mathrm{O}_{3}$ samples were modeled as alternately overlapping five layers, each of them having their intrinsic properties. The main objective is to depict the effect of the $\mathrm{Al}_{2} \mathrm{O}_{3}$ content on $\mathrm{pSi} / \mathrm{SnO}_{2}$ microstructural and opto-electronic properties. 


\section{Experimental detail}

Electrochemical anodization was used to prepare the porous $\mathrm{Si}(\mathrm{pSi})$ layer. A current density of $10 \mathrm{~mA} / \mathrm{cm}^{2}$ was maintained for a silicon substrate immersed in a hydrofluoric acid (HF) Solution. The obtained pSi layer was etched in an acid mixture solution (HNO3: 10\%, HF: 20\%, $\mathrm{H}_{2} \mathrm{O}_{2}: 70 \%$ ) followed then rinsed with distilled water and dried under oxygen to yield a pSi model with an ordered pore structure. The CVD and PVD methods served to deposit on the pSi substrate a thin layer of tin dioxide $\left(\mathrm{SnO}_{2}\right)$ using $\mathrm{Snl}_{2}$ and $\mathrm{O}_{2}$ respectively as reagents. $\mathrm{SnO}_{2}$ in the first place and therefore $\mathrm{Al}_{2} \mathrm{O}_{3}$ at different concentrations.

$$
\left(\mathrm{SnCl}_{2}+2 \mathrm{H}_{2} \mathrm{O}\right)_{\mathrm{s}}+\left(\mathrm{O}_{2}\right)_{\mathrm{g}} \longrightarrow\left(\mathrm{SnO}_{2}\right)_{\mathrm{s}}+\left(2 \mathrm{H}_{2} \mathrm{O}\right)_{\mathrm{g}}+\left(\mathrm{Cl}_{2}\right)_{\mathrm{g}}
$$

The thin film of $\mathrm{SnO}_{2}$ was grown by CVD on $\mathrm{pSi}$. A vertical CVD configuration was designed to lay the films [25]. Before depositing the film, the chamber was placed under vacuum at 0.1 mbar. The tin precursor was a powdered tin (II) iodide $\left(\mathrm{SnI}_{2}\right.$, 99\%, from Alfa Aesar Company) for the $\mathrm{SnO}_{2}$ deposition. The $\mathrm{SnI}_{2}$ evaporation rate was kept between 0.004 and $0.6 \mathrm{~g} / \mathrm{h}$ by setting the $\mathrm{SnI} 2$ reservoir temperature in the range of 28 to $460{ }^{\circ} \mathrm{C}$. A flow of argon gas is used to carry the $\mathrm{SnI}_{2}$ vapor to the reaction zone in a separate quartz tube. The substrates were sited on a quartz glass sample holder, about $10 \mathrm{~cm}$ away from the orifice of this separate tube. The sample holder rotation was set at $19 \mathrm{rpm}$ during deposition to assure uniform deposition. The $\mathrm{O}_{2}$ gas flow rate was varied from 10 to $200 \mathrm{sccm}$. The carrier gas (Ar) and the reactive gas $\left(\mathrm{O}_{2}\right)$ flows were monitored by mass flow regulators. The chamber pressure was kept at 46 mbar during the deposition. The deposition temperature was set to $550^{\circ} \mathrm{C}$. The film thickness is estimated to $190 \mathrm{~nm}$ for $37 \mathrm{~min}$ deposition time. The $\mathrm{Al}_{2} \mathrm{O}_{3}$ films were deposited with different concentrations: (a) $0 \%$ (b) $3.7 \%$ (c) $7,4 \%$ (d) $11,1 \%$ (e) $14,8 \%$ (f) $19 \%$ relative to the concentration of $\mathrm{SnO}_{2}$ by a $\mathrm{RF}$ reactive magnetron sputtering at a deposition temperature of $660^{\circ} \mathrm{C}$.

The obtained $\mathrm{pSi} / \mathrm{SnO}_{2} / \mathrm{Al}_{2} \mathrm{O}_{3}$ structure was then thermally treated under oxygen and introduced into an oven under oxygen flow at a temperature equal to $1500^{\circ} \mathrm{C}$. 


\section{Characterizations}

The crystallographic structures of $\mathrm{pSi} / \mathrm{SnO}_{2} / \mathrm{Al}_{2} \mathrm{O}_{3}$ were determined by $\mathrm{X}$-ray diffraction (XRD) using a Bruker D8 advance X-ray diffractometer equipped with $\mathrm{CuK} \alpha$ radiation $(\lambda \mathrm{CuK} \alpha=1.5406 \AA)$. To fully recognize the distribution of crystals on the surface and the correlation with optoelectronic properties the surface microstructure and morphology were analyzed using the scanning electron microscope (SEM) and the atomic force microscope (AFM) techniques. The optical properties of $\mathrm{pSi} / \mathrm{SnO}_{2} / \mathrm{Al}_{2} \mathrm{O}_{3}$ were investigated usinf Spectroscopic Ellipsometry (SE) analysic were recorded with a GES5 SOPRA equipped with a rotating polarizer SE, in the wavelength interval from 300 to $1200 \mathrm{~nm}$ with a step of $1 \mathrm{~nm}$ under incidence angle of $78^{\circ}$. Data acquisition and analysis were performed using the Winelli II Software (version 2.0.0.0). SE served to obtain an accurate determination of film thickness, the percent of each component, including vacuum, refractive index (n) and extinction coefficient ( $\mathrm{k}$ ) Optical dispersion coefficients ' $\mathrm{n}$ ' and ' $\mathrm{k}$ ' were calculated for the $\mathrm{pSi} / \mathrm{SnO}_{2} / \mathrm{Al}_{2} \mathrm{O}_{3}$ thin films structure using the BEMA model. The electrical measurements configuration was carried using a Hewlett-Packard HP 4192 impedance analyzer. For this purpose, two silver electrodes that were painted on both ends of the sample. The electrical tests were carried out over a large interval of temperature from 190 to $370 \mathrm{~K}$ and a frequency varying in $5 \mathrm{~Hz}-13 \mathrm{MHz}$ range.

\section{Results and discussion}

\subsection{Morphology and structure of $\mathrm{pSi} / \mathrm{SnO}_{2} / \mathrm{Al}_{2} \mathrm{O}_{3}$}

\subsubsection{Energy dispersive X-ray (EDX) analysis}

The EDX results of film composition were obtained. Figure 1 displays an EDX spectral representation of the $\mathrm{pSi} / \mathrm{SnO}_{2} / \mathrm{Al}_{2} \mathrm{O}_{3}$ thin films and the relative elementary composition. Mainly $\mathrm{Si}, \mathrm{O}, \mathrm{Al}$, and $\mathrm{Sn}$ were present in the samples. The atomic percent of these elements were $69.3 \%, 20.5 \%, 7.5 \%$, and $1.4 \%$, respectively. EDX surface mapping (Fig. 2) of $\mathrm{pSi} / \mathrm{SnO}_{2} / \mathrm{Al}_{2} \mathrm{O}_{3}$ clearly shows a uniform distribution of all the elements throwing the whole surface.

\subsubsection{SEM analysis}

Figure 3 shows a cross section view of $\mathrm{pSi} / \mathrm{SnO}_{2} / \mathrm{Al}_{2} \mathrm{O}_{3}$ layers after coating as a 
function of alumina concentration: (a) $0 \%$, (b) $3.5 \%$, (c) $7 \%$, (d) $11 \%$, (e) 19\%, (f) $24 \%$ relative to the concentration of $\mathrm{Sn}$. Notably, the layers begin to grow as the alumina crystals are incorporated in $\mathrm{pSi} / \mathrm{SnO}_{2}$ pores. Small pseudo -pyramids are thus formed by nucleation [26,27]. The sectional image shows the incorporation of alumina crystals in the pores of the $\mathrm{pSi} / \mathrm{SnO}_{2}$. A surface layer of alumina also emerged. The SEM micrograph of the $\mathrm{pSi} / \mathrm{SnO}_{2} / \mathrm{Al}_{2} \mathrm{O}_{3}$ structure reveals the coalescence of small nanoparticles on the surface. The rate of voids decreases in accordance with the percent of deposited alumina; which improves the crystallization of the film.

\subsubsection{AFM analysis}

The surface roughness of the sample and the alteration caused by $\mathrm{Al}_{2} \mathrm{O}_{3}$ on the surface morphology of $\mathrm{pSi} / \mathrm{SnO}_{2}$ were studied via AFM. According to Figure 4, the surface morphology of the $\mathrm{pSi} / \mathrm{SnO}_{2} / \mathrm{Al}_{2} \mathrm{O}_{3}$ films is uniform and homogenous. Upon the deposition of $\mathrm{Al}_{2} \mathrm{O}_{3}$ at different concentrations, the particles undergo an increase of the distribution consistency, a change of the size, the movement of the atoms position and a recrystallization. The minor spherical grains agglomerate depending on the alumina concentration. Table 1 illustrates the particle size, the mean square (RMS) and the roughness as obtained for these films.

\subsubsection{X-ray diffraction analysis}

Evolution of XRD spectra of $\mathrm{pSi} / \mathrm{SnO}_{2} / \mathrm{Al}_{2} \mathrm{O}_{3}$ samples annealed at $660^{\circ} \mathrm{C}$ is presented in Fig.5. Eight diffraction peaks corresponding respectively to $\mathrm{SiO}_{2}$ [101], $\mathrm{Al}_{2} \mathrm{O}_{3}$ [311], $\mathrm{Al}_{2} \mathrm{O}_{3}$ [511], $\mathrm{SnO}_{2}$ [115], and $\mathrm{SnO}_{2}$ [120] were depicted.

To calculate the mean crystallite size of $\mathrm{Al}_{2} \mathrm{O}_{3}$, we used Debey Scherrer's equation

$$
\text { [30]: } \quad D=\frac{0.9 \lambda}{\beta \cos \theta}
$$

with $\mathrm{D}$ is the average size of crystallite, $\lambda$ is the wavelength of the $\mathrm{X}$-rays, $\theta$ is the Bragg diffraction angle, and $\beta$ is the adjusted FWHM. The $\mathrm{Al}_{2} \mathrm{O}_{3}$ crystallites size increases from $2.8 \mathrm{~nm}$ to $6.7 \mathrm{~nm}$ as the $\mathrm{Al}_{2} \mathrm{O}_{3}$ concentration increases. The crystallites size increase was attributed to a diffusion of aluminum crystals from the surface towards the interior of the pSi coated with $\mathrm{SnO} 2$, which improved the crystallinity of 
the structure of the films.

\subsection{Opto-electrical characterization}

\subsubsection{Optical analysis}

The ellipsometric results are interpreted via an optical model which exactly matches the configuration of the studied surface. The samples contained porous layers of different compositions superimposed in parallel, as shown in figure 6.The compositions of each layer are detailed in Table 1. Our proposed model is in congruency with De La et et al. [29, 30]. Based on the approximation of the effective medium (EMMA) of Bruggeman [31], Fig. 6 shows a model consisting of 4 vertically superimposed layers of different densities .The proposed structure is composed of vacuum mixtures, $\mathrm{SnO}_{2}, \mathrm{Si}$, and $\mathrm{Al}_{2} \mathrm{O}_{3}$ layers, each having its intrinsic compositions. The optical model is accepted when the root means squared error (RMSE) is inferior to $9 \%$ [32].

$$
R M S E=\sqrt{\frac{1}{2 N-P-1} \sum_{j=1}^{N}\left[\left(\tan \psi_{j}^{m}-\tan \psi_{j}^{s}\right)^{2}+\left(\cos \Delta_{j}^{m}-\cos \Delta_{j}^{s}\right)^{2}\right]}
$$

The physical parameters $(\mathrm{n}, \mathrm{k})$ are adequately determined when the model fits the experimental $\tan \psi$ and $\cos \Delta$ data. Fig. 7 illustrates the used multilayer model. $\Psi$ and $\Delta$ are the so-called ellipsometric parameters. They respectively stand for the amplitude ratio and phase difference between the p-polarization and s-polarization components of the polarization state of the incident light. $\mathrm{N}$ is the number of points, $\mathrm{P}$ the number of parameters, $\mathrm{m}$ the measured spectra and $\mathrm{s}$ the simulated spectra. Optimization resulted in congruency between the experimental results and theoretical fit. The curves in Fig. 8 exhibit a close agreement throughout the spectral range. This same method is also useful to measure the thickness of the studied layer based on the interference between the reflected rays. Table 1 records the layer thickness and the corresponding RMSE values. The optical constants including the refractive index (n) and the extinction coefficient $(\mathrm{k})$ were extracted and evaluated as a function of the $\mathrm{Al}_{2} \mathrm{O}_{3}$ concentration (Fig.8). The refractive index $\mathrm{n}$ and the extinction coefficient $\mathrm{k}$ variation depend on the concentration of $\mathrm{Al}_{2} \mathrm{O}_{3}$, which is attributed to the diffusion of cations along the grain boundaries of $\mathrm{Al}_{2} \mathrm{O}_{3}$. An opposite flux of vacancies was thus 
created towards the surface of the $\mathrm{pSi} / \mathrm{SnO}_{2}$ layer. The vacancies can condense and then reach the $\mathrm{SnO}_{2} / \mathrm{Al}_{2} \mathrm{O}_{3}$ interface to form cavities under the $\mathrm{Al}_{2} \mathrm{O}_{3}$ grain boundaries.

\subsubsection{Conductivity measurements}

The complex impedance was measured on all the $\mathrm{pSi} / \mathrm{SnO}_{2} / \mathrm{Al}_{2} \mathrm{O}_{3}$ samples within a frequency range between $100 \mathrm{~Hz}$ and $13 \mathrm{MHz}$, and temperature $\left(190-370^{\circ} \mathrm{C}\right)$. The corresponding diagrams are shown in the representation of Nyquist $Z^{\prime \prime}=f\left(Z^{\prime}\right)$ in Fig.9. In practice, several contributions to a dielectric response of an oxidized materials such as grains, grain boundaries, interface are available. The semicircles relative to $\mathrm{pSi} / \mathrm{SnO}_{2} / \mathrm{Al}_{2} \mathrm{O}_{3}$ display different radii (dissimilar to Debye). This effect is attributed a dipolar system involving multi-relaxation processes [33]. We conclude that all samples are semiconductors. In addition, the resistance R0 changed as a function of the deposited alumina concentrations. The peak $Z^{\prime \prime}$ intensity variation pleads in favor of a low-capacity semiconductor region assigned to the response of the $\mathrm{SnO}_{2}$ grain embedded in alumina, and the variation of vacuum rate among the samples.

\subsubsection{Imaginary part of the impedance}

The evolution of the imaginary part $\mathrm{Z}$ " of the $\mathrm{pSi} / \mathrm{SnO}_{2} / \mathrm{Al}_{2} \mathrm{O}_{3}$ sample impedance with frequency at several temperatures is shown in Fig. 10. A maximum of $Z$ " gives the frequency fmax relaxations as governed by the Arrhenius [34-37] law:

$$
f_{\max }=f_{0} e^{-\frac{E_{a\left(z^{\prime \prime}\right)}}{K_{B} T}}
$$

Where $\mathrm{Ea}\left(\mathrm{Z}^{\prime \prime}\right)$ is the activation energy, $\mathrm{f}_{0}$ is the characteristic phonon frequency and $\mathrm{K}_{\mathrm{B}}$ is the Boltzmann constant. The activation energy relative to the relaxation process $\mathrm{Ea}\left(Z^{\prime \prime}\right)$ was calculated according to Eq. (4) by the plotting $\log (\mathrm{fmax})$ vs. reciprocal temperature. Table 2 shows that the increase of activation energy with alumina content to $2.31 \mathrm{eV}$, with an $\mathrm{Al}_{2} \mathrm{O}_{3}$ concentration equal to $19 \%$ and its decrease beyond this rate. This variation is attributed to the incorporation of $\mathrm{Al}_{2} \mathrm{O}_{3}$ in $\mathrm{pSi} / \mathrm{SnO}_{2}$, and the decrease in the vacuum rate, that facilitates the rate of jump activated thermally. The decrease in $\mathrm{Ea}\left(\mathrm{Z}^{\prime \prime}\right)$ when $\left[\mathrm{Al}_{2} \mathrm{O}_{3}\right]$ is equal to $24 \%$ is a possible result of the nucleation of a new surface layer where $\mathrm{Al}_{2} \mathrm{O}_{3}$ crystals are very far apart; which ceases the 
thermally activated jump [38]. This behavior can also be assigned to vacancies in deposited alumina and to interface defects resulting from Tin dioxide vacancies occupied by oxygen atoms as the surface was coated with $\mathrm{Al}_{2} \mathrm{O}_{3}$. The values of $\mathrm{Ea}\left(Z^{\prime \prime}\right)$ for $\mathrm{pSi} / \mathrm{SnO}_{2} / \mathrm{Al}_{2} \mathrm{O}_{3}$ (Fig. 9) reveal two activation energy domains with temperature. in the variation of the electrical properties of the prepared thin film is due to the presence of a new oxide formed in the pores of $\mathrm{Si}$. This phenomenon was favored by the transfer of the oxygen supplied during the external oxide dissociation. The oxide dissociation is due to the excessive number of cation created at the grain boundaries, thus diffusing through the layer. Conductivity abides by power law with the pulsation given by the equation below [39]:

$\sigma_{t}=\sigma_{d c}+\sigma_{a c}(T, w)$

Where $\omega$ is the angular frequency, $T$ is the absolute temperature, $\sigma_{d c}$ is the independent frequency conductivity or dc conductivity and $\sigma_{\mathrm{ac}}$ is the ac conductivity.

\subsubsection{Frequency dependence of ac conductivity}

The conduction mechanism of $\mathrm{pSi} / \mathrm{SnO}_{2} / \mathrm{Al}_{2} \mathrm{O}_{3}$ dispersions was determined by calculating the conductivity values of dispersions over the frequency range $[1 \mathrm{~Hz}, 10$ $\mathrm{Hz}]$ and at different temperatures as shown in Fig.11. The alternative conductivity oac at different temperatures was modelled by Jonscher's universal power law:

$$
\sigma_{d c}=A w^{s}
$$

A is the constant dependent on temperature, $S$ is the material property which can have any value between 0 and 1 , and $\sigma_{\mathrm{ac}}$ is the ac conductivity. The evolution of $\mathrm{S}$ with temperature depends on the conduction mechanism. The exponent $\mathrm{S}$ expresses the relative reduction in the size of alumina crystals with frequency and is defined as follows:

$$
S=\frac{d \ln \sigma_{a c}}{d \ln w}
$$

The frequency exponent $S$ raised from the slope of $\ln (\sigma t)$ [Fig. 12(a)] declines in parallel with temperature. The charge transfer, described as a superposition of the various conduction phenomena, is responsible for these results. $\mathrm{pSi} / \mathrm{SnO}_{2} / \mathrm{Al}_{2} \mathrm{O}_{3}$ 
morphology contains metal islands surrounded by amorphous alumina regions. Electronic wave functions lie in amorphous regions; but they can be delocalized in metallic regions. Metal conduction takes place in the metal islands while the charge transfer, is done by jumping in the amorphous regions. an inter-fibrillar and an intrafibrillar conductions occur inside the metal region by hopping loads from one end of a chain to the other. The equation correlated with the model is written as follows [40]:

$$
S=1-\frac{6 K_{B T}}{W_{m}}
$$

$\mathrm{T}$ is the absolute temperature, $\mathrm{Wm}$ and $\mathrm{K}_{\mathrm{B}}$ are respectively, the maximum height of the barrier and the Boltzmann constant. The value of Wm (Table 2) is determined from the adaptation of $\mathrm{S}$ as $1-\frac{6 K_{B T}}{W_{m}} T$

Wm was found to increase slightly in accordance with the concentration of $\mathrm{Al}_{2} \mathrm{O}_{3}$ up to $1.81 \mathrm{eV}$, then it decreases slightly. Arrhenius law was applied to interpret the experimental results of dc conductivity [41]:

$$
\sigma_{d c}=\frac{c}{T} e^{-\frac{E_{a(d c)}}{K_{B} T}}
$$

Whereby, $\mathrm{C}$ is a constant and Ea is the activation energy for the hopping conduction. Figure $12(\mathrm{~b})$ shows the plot of $\ln \left(\sigma_{\mathrm{dc}} \cdot \mathrm{T}\right)$ vs.1000/T for $\mathrm{pSi} / \mathrm{SnO}_{2} / \mathrm{Al}_{2} \mathrm{O}_{3}$ thin films. According to Arrhenius law, the dc conductivity of the films decreases when temperature increases. This evolution shows the thermal activation mechanism of the electrical conduction, which indicates that the $\mathrm{pSi} / \mathrm{SnO}_{2} / \mathrm{Al}_{2} \mathrm{O}_{3}$ hybrid system has a semiconductor behavior. The activation energy Ea $(\mathrm{dc})$ is extracted from the slope of $\ln (\sigma \mathrm{dc} \cdot \mathrm{T}) \mathrm{vs} .1000 / \mathrm{T}$. Ea(dc) values are summarized in Table 2 . The electrical results prove that, in thermal fluctuation, sufficient energy can be supplied to a dipole hopping across the potential barrier from one position to another equilibrium position [42-44].

\section{Conclusion}

The opto-electrical properties of a $\mathrm{SnO}_{2} / \mathrm{Al}_{2} \mathrm{O}_{3}$ deposit in a porous silicon layer were investigated. The structural properties were found to depend significantly on the $\mathrm{Al}_{2} \mathrm{O}_{3}$ 
concentration. XRD spectra showed that the concentration of $\mathrm{Al}_{2} \mathrm{O}_{3}$ deposited on $\mathrm{pSi} / \mathrm{SnO}_{2}$ was vital to improving crystallinity. After the deposition of $\mathrm{Al}_{2} \mathrm{O}_{3}$ under oxygen on $\mathrm{pSi} / \mathrm{SnO}_{2}$, the structure tends to crystallize for a temperature that reaches $660^{\circ} \mathrm{C}$. The ellipsometric study of $\mathrm{pSi} / \mathrm{SnO}_{2} / \mathrm{Al}_{2} \mathrm{O}_{3}$ shows the improvement of optical properties (refractive index, extinction coefficient) as a function of the $\mathrm{Al}_{2} \mathrm{O}_{3}$ concentration. Consequently, the refractive index is raised while the extinction coefficient becomes lower with the concentration of $\mathrm{Al}_{2} \mathrm{O}_{3}$. This change is attributed to the progressive pores filling as a function of $\mathrm{Al}_{2} \mathrm{O}_{3}$ concentration and structure alteration. Moreover, according to the impedance measurements, the ac conductivity obeys the universal power law. The transport of charge carriers was using the $\mathrm{CBH}$ model. these results exhibits a novel semiconducting behavior that is suitable for thin film engineering and functional coating applications

\section{Author Declarations :}

- Ethics approval and consent to participate. applicable for that section.

- Consent for publication applicable for that section.

- Availability of data and materials .applicable for that section.

- Competing interests .applicable for that section.

- Funding. applicable for that section.

- Authors' contributions applicable for that section.

\section{- Acknowledgements}

The authors would like to thank prof Wisem Dimassi, Mounir Gaidi, Rachid Ouertani, Hatem Ezzaouia from laboratory Nanomaterials and Systems for Renewable Energies, Higher Institute of Environmental Sciences and Technologies of Borj-Cédria (ISSTE) for cooperation and discussions, finly I financial support provided by the laboratories and characterization units belonging to the University of Carthage, is gratefully acknowledged.

\section{References:}


[1] Paulowicz, I.; Hrkac, V.; Kaps, S.; Cretu, V.; Lupan, O.; Braniste, T.; Duppel, V.; Tiginyanu, I.; Kienle, L.; Adelung, R. Three-dimensional $\mathrm{SnO}_{2}$ nanowire networks for multifunctional applications: From high-temperature stretchable ceramics to ultra responsive sensors. Am. Ceram. Soc. Bull. 2015, 94, 21.

[2] Guan, C.; Wang, X.; Zhang, Q.; Fan, Z.; Zhang, H.; Fan, H.J. Highly stable and eversible lithium storage in $\mathrm{SnO}_{2}$ nanowires surface coated with a uniform hollow shell by atomic layer deposition. Nano Lett. 2014, 14, 4852-4858.

[3] Kim, D.H.; Shin, D.Y.; Lee, Y.G.; An, G.H.; Han, J.H.; Ahn, H.J.; Choi, B.J. Effects of $\mathrm{SnO} 2$ layer coated on carbon nanofiber for the methanol oxidation reaction. Ceram. Int. 2018, 44, 19554-19559.

[4] Park, M.; Kim, J.Y.; Son, H.J.; Lee, C.H.; Jang, S.S.; Ko, M.J. Low-temperature solution-processed $\mathrm{Li}$-doped $\mathrm{SnO}_{2}$ as an effective electron transporting layer for highperformance flexible and wearable perovskite solar cells. Nano Energy 2016, 26, $208-215$.

[5] Chu, H.C.; Shen, Y.S.; Hsieh, C.H.; Huang, J.H.; Wu, Y.H. Low-voltage operation of $\mathrm{ZrO} 2$-gated n-type thin-film transistors based on a channel formed by hybrid phases of $\mathrm{SnO}$ and $\mathrm{SnO}_{2}$. ACS Appl. Mater. Interfaces 2015, 7, 15129-15137.

[6] Jarzebski, Z.M.; Marton, J.P. Physical properties of $\mathrm{SnO}_{2}$ materials. J.

Electrochem. Soc. 1976, 123, 299-310.

[7] Manifacier, J.C.; De Murcia, M.; Fillard, J.P.; Vicario, E. Optical and electrical properties of $\mathrm{SnO}_{2}$ thin films in relation to their stoichiometric deviation and their crystalline structure. Thin Solid Films 1977, 41, 127-135.

[8] Minami, T.; Nanto, H.; Takata, S. Highly conducting and transparent $\mathrm{SnO}_{2}$ thin films prepared by RF magnetron sputtering on low-temperature substrates. Jpn. J. Appl. Phys. 1988, 27, L287-L289.

[9] Liu, Y.; Koep, E.; Liu, M. A highly sensitive and fast-responding $\mathrm{SnO}_{2}$ sensor fabricated by combustion chemical vapor deposition. Chem. Mater. 2005, 17, $3997-$ 4000.

[10] Korotcenkov, G.; Brinzari, V.; Schwank, J.; Dibattista, M.; Asiliev, A. 
Peculiarities of $\mathrm{SnO}_{2}$ thin film deposition by spray pyrolysis for gas sensor application. Sens. Actuators B 2001, 77, 244-252.

[11] Jonas Sundqvist, Jun Lu, Mikael Ottosson, Anders Harsta, Growth of $\mathrm{SnO}_{2}$ thin films by atomic layer deposition and chemical vapour deposition: A comparative study, Thin Solid Films 514 (2006) 63-68.

[12] Aris Doyan, Susilawati and Yanika Diah Imawantic, Synthesis and Characterization of $\mathrm{SnO}_{2}$ Thin Layer with a Doping Aluminum is Deposited onQuartz Substrates, AIP Conference Proceedings 1801, 020005 (2017).

[13] K.L. Chopra, S. Major, D.K. Pandya, Thin Solid Films 102 (1983) 1.

[14] J. Joseph, V. Mathew, K.E. Abraham, Cryst. Res. Technol. 41 (2006) 1020.

[15] Sundaram KB, Bhagavat GK. X-ray and electron diffraction studies of chemi cally vapour-deposited tin oxide films. Thin Solid Films 1981;78:35e 40.

[16] Kim KH, Chun JS. X-ray studies of SnO2prepared by chemical vapour deposition. Thin Solid Films 1986;141:287e 95.

[17] Sundqvist J, Ottosson M, Hårsta A. CVD of epitaxial $\mathrm{SnO}_{2}$ films by the $\mathrm{SnI}_{4} / \mathrm{O}_{2}$ precursor combination. Chem Vap Depos 2004;10:77e82.

[18]Vepřrek,S.Plasma-induced and plasma-assisted chemical vapour deposition, Thin Solid Films ,130, 135-154(1985).

[19] W. Zou, R.D. Gonzalez, Appl. Catal. A 102 (1993) 181-200.

[20] Jeurgens LPH, Sloof WG, Tichelaar FD and Mittemeijer EJ. Structure and morphology of aluminum-oxide films formed by thermal oxidation of aluminum. Thin Solid Films . 2002; 418(2):89-101.

[21] Xuan Y, Lin HC, Ye PD and Wilk GD. Capacitance-voltage studies on enhancement-mode InGaAs metal-oxide-semiconductor field-effect transistor using atomic-layer-deposited Al2O3 gate dielectric. Applied Physics Letters. 2006; 88(26):263518.

[22] Lin HC, Ye PD and Wilk GD. Current-transport properties of atomic-layer- 
deposited ultrathin Al2O3 on GaAs. Solid-State Electronics. 2006; 50(6):1012-1015. [23] Ghrib, M. Gaidi, M. Khedher, N. Ghrib T., Ben Salem, M. Ezzaouia ,H, Morphological and optical properties changes in nanocrystalline Si (nc-Si) deposited on porous aluminum nanostructures by plasma enhanced chemical vapor deposition for Solar energy applications, Appl. Surf.Sci,11,164(2011).

[24] M. Ghrib, B. Tlili, M. Razeg, R. Ouertani, M. Gaidi, H. Ezzaouia , Effect of $\mathrm{Al}_{2} \mathrm{O}_{3}$ decoration on the opto-electrical properties of a porous $\mathrm{Si} / \mathrm{Cr}_{2} \mathrm{O}_{3}$ composite, Opto-Electronics Review, 1896-3757/ 2020.

[25] Eisermann S, Kronenberger A, Laufer A, Bieber J, Haas G, Lautenschlager S, et al. Copper oxide thin films by chemical vapor deposition: synthesis, Caracterization and electrical properties. Phys Status Solidi A 2012;209:531-6.

[26] Chayen, N. E., Saridakis, E., El-Bahar, Y. \& Nemirovsky, R. Porous silicon: an effective nucleation-inducing material for protein crystallization. J. Mol. Biol. 312, 591-595 (2001).

[27] Kluth, O. et al. Modified Thornton model for magnetron sputtered zinc oxide,film structure and etching behaviour. Thin Solid Films 442, 80-85 (2003).

[28] M. Ghrib, M.Gaidi, N. Khedher, T.Ghrib,M. Ben Salem, H. Ezzaouia:

Morphological and optical properties changes in nanocrystalline $\mathrm{Si}$ (nc-Si) deposited on porous aluminum nanostructures by plasma enhanced chemical vapor deposition for Solar energy applications. Appl. Surf.Sci.11 (2011) 164.

[29] Matthew M. Hawkeye Michael J. Brett : Glancing angle deposition: Fabrication, properties, and applications of micro- and nanostructured thin films. September 2007 Journal of Vacuum Science \& Technology A Vacuum Surfaces and Films 25(5) DOI: 10.1116/1.2764082 .

[30] Thornton JA. J Vac Sci Technol 1974;11:666

[31] B.D. Cullity, S.R. Stock, Elements of X-Ray Diffraction third ed. Prentice Hall, Upper Saddle River, New Jersey, 2001.

[32] Kezzoula F, Hammouda A, Kechouane M, Simon P, Abaidia SEH, Keffous A, Cherfi R, Menari H, Manseri A: Aluminium-induced crystallization of amorphous 
silicon films deposited by DC magnetron sputtering on glasses.Appl Sur f S ci 2011,257: $9689-9693$

[33] G.S. Huang, X.L. Wu, G.G. Siu, Paul K. Chu, Solid State Commun. 137 (2006) 621.

[34] J. De Laet, H. Terryn, J. Vereecken, hin Solid Films 320 (1998) 241.

[35] D.A.G. Bruggeman, Ann. Phys. 5 (1935) 638.

[36] C. Thirmal, P. Murugavel, V. Subramanian, Curr. Appl. Phys. 14 (2014) 688.

[37] H. Rahmouni, A. Selmi, K. Khirouni, N. Kallel, J. Alloys Compd. 533 (2012) 93.

[38] Q. Liu, B. Peng, M. Shen, B. Hu, Q. Chen, Solid State Ionics. 255 (2014) 74.

[39] V.H. Mudavakkat, M. N-A-Alam, K.K. Bharathi, S. AlFaify, A. Dissanayake, A. Kayani, C.V. Ramana, Thin Solid Films 519 (2011) 7947.

[40] A.K. Jonscher, Nature 267 (1977) 673.

[41] P. Sivakumar, R. Ramesh, A. Ramanand, S. Ponnusamy, C. Muthamizhchelvan, J. Alloys Compd. 537 (2012) 203.

[42] M. Haj Lakhdar, B. Ouni, M. Amlouk, Mater. Sci. Semicond. Process. 19 (2014) 32.

[43] G.E. Pike, Phys. Rev. B 6 (1972) 1572.

[44] B. Roy, S. Chakrabarty,O. Mondal, M. Pal, A. Dutta, Mater. Charact.70 (2012) 1.

\section{Liste figures captions}

Fig. 1. The EDX analysis of $\mathrm{pSi} / \mathrm{SnO}_{2} / \mathrm{Al}_{2} \mathrm{O}_{3}$ thin films.

Fig. 2. EDX-mapping of $\mathrm{pSi} / \mathrm{SnO}_{2}$ coated with $\mathrm{Al}_{2} \mathrm{O}_{3}$ at different concentration..

Fig. 3. SEM cross-sectional images of $\mathrm{pSi} / \mathrm{SnO}_{2}$ coated with $\mathrm{Al}_{2} \mathrm{O}_{3}$.

Figure 4: $\mathrm{AFM}$ images of $\mathrm{pSi} / \mathrm{SnO}_{2}$ coated with $\mathrm{Al}_{2} \mathrm{O}_{3}$ at different concentration

Fig.5. X-ray diffraction patterns $\mathrm{pSi} / \mathrm{SnO}_{2}$ coated with $\mathrm{Al}_{2} \mathrm{O}_{3}$ at different concentration.

Fig. 6. Multilayer model used to fit the pSi/SnO $2 / \mathrm{Al}_{2} \mathrm{O}_{3}$ structure with different $\mathrm{Al}_{2} \mathrm{O}_{3}$ concentration. 
Fig. 7. Experimental (Symbols) and fitted (Red-lines) SE data of $\mathrm{pSi} / \mathrm{SnO}_{2}$ coated with $\mathrm{Al}_{2} \mathrm{O}_{3}$ at different concentration.

Fig. 8. Effect of $\mathrm{Al}_{2} \mathrm{O}_{3}$ concentration on the refractive index $\mathrm{n}$ and the extinction coefficient $\mathrm{k}$ of $\mathrm{pSi} / \mathrm{SnO}_{2} / \mathrm{Al}_{2} \mathrm{O}_{3}$ coated with $\mathrm{Al}_{2} \mathrm{O}_{3}$ at different concentration.

Fig. 9. Complex impedance spectra of $\mathrm{pSi} / \mathrm{SnO}_{2} / \mathrm{Al}_{2} \mathrm{O}_{3}$.

Fig. 10. Angular dependance of $\mathrm{pSi} / \mathrm{SnO}_{2} / \mathrm{Al}_{2} \mathrm{O}_{3}$.

Fig. 11. Angular dependance of ac conductivity of $\mathrm{pSi} / \mathrm{SnO}_{2} / \mathrm{Al}_{2} \mathrm{O}_{3}$ thin films.

Fig. 12. (a) Temperature dependence of the exponent $\mathrm{S}$ and (b) dc conductivity curve for $\mathrm{pSi} / \mathrm{SnO}_{2} / \mathrm{Al}_{2} \mathrm{O}_{3}$. The dots are the experimental points and the solid line is the least-square straight line fit.

\section{Table caption:}

Table 1: Layer thicknesses and film porosity at different concentration of $\mathrm{Al}_{2} \mathrm{O}_{3}$.

Table 2: Activation energy Ea and barrier height $\mathrm{Wm}$ of $\mathrm{pSi} / \mathrm{SnO}_{2} / \mathrm{Al}_{2} \mathrm{O}_{3}$.. 
Figures

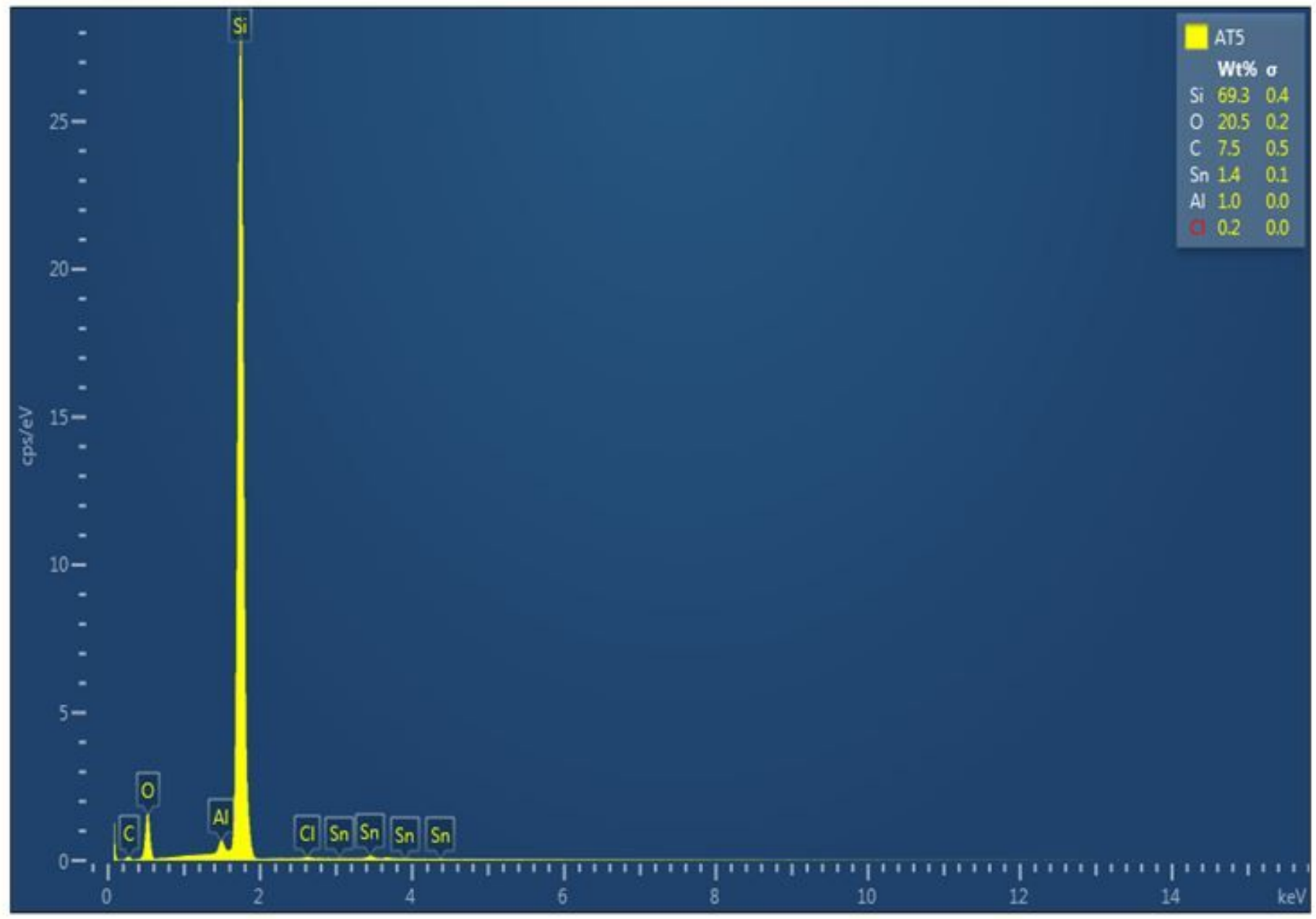

Figure 1

The EDX analysis of $\mathrm{pSi} / \mathrm{SnO} 2 / \mathrm{Al} 2 \mathrm{O} 3$ thin films. 


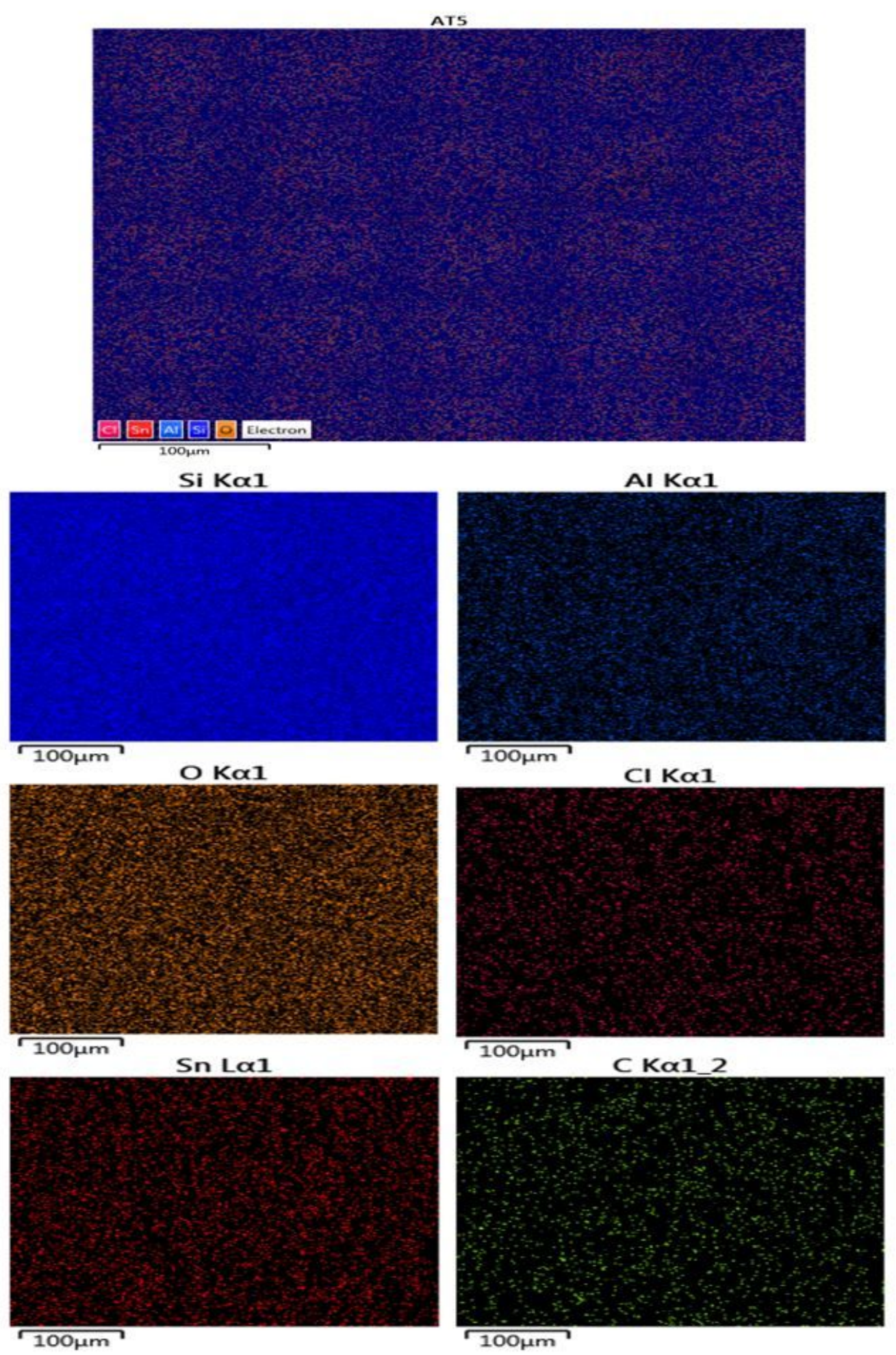

Figure 2

EDX-mapping of pSi/SnO2 coated with Al2O3 at different concentration.. 


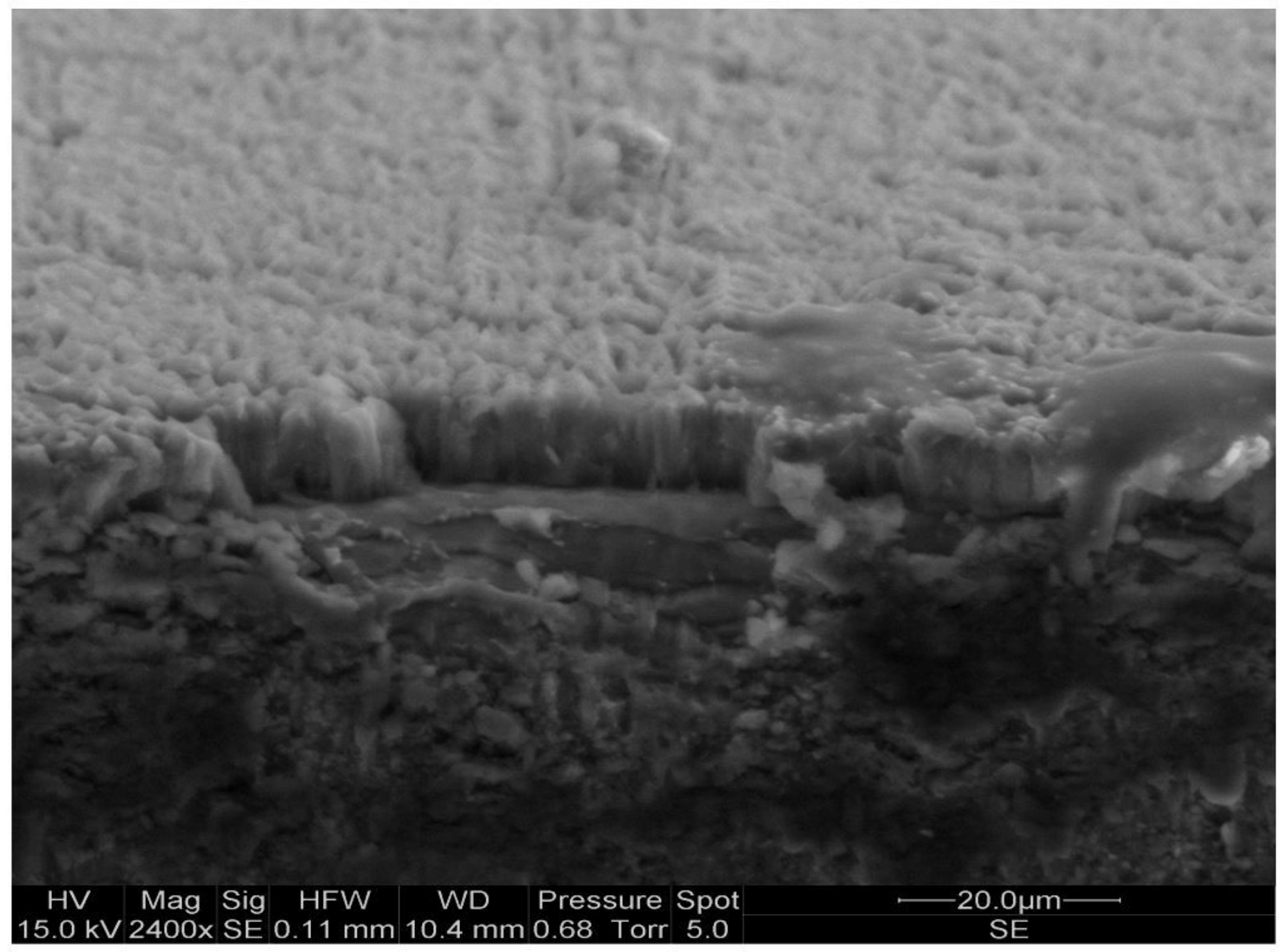

Figure 3

SEM cross-sectional images of pSi/SnO2 coated with Al2O3 . 

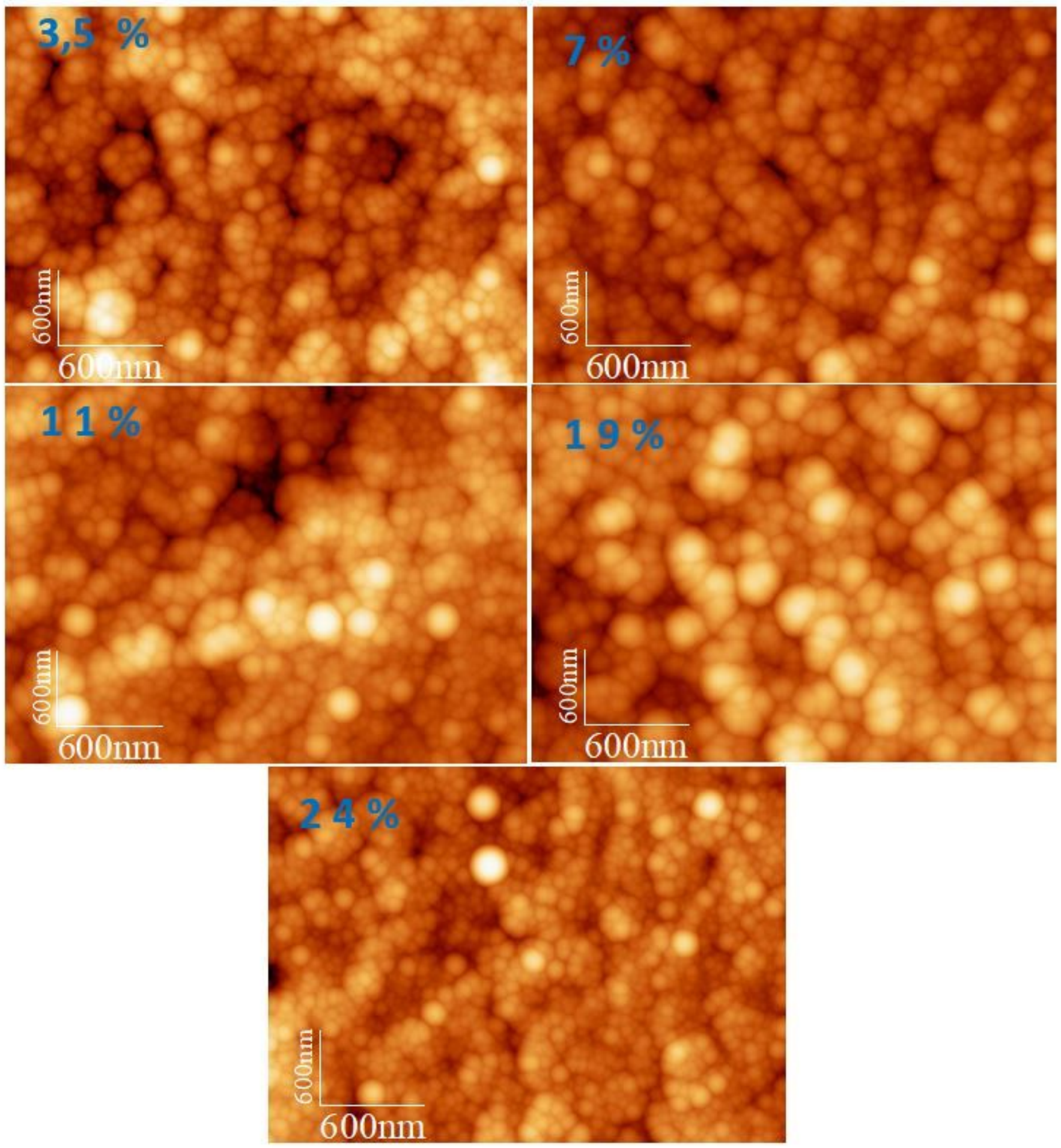

Figure 4

AFM images of $\mathrm{pSi} / \mathrm{SnO} 2$ coated with $\mathrm{Al} 2 \mathrm{O} 3$ at different concentration 


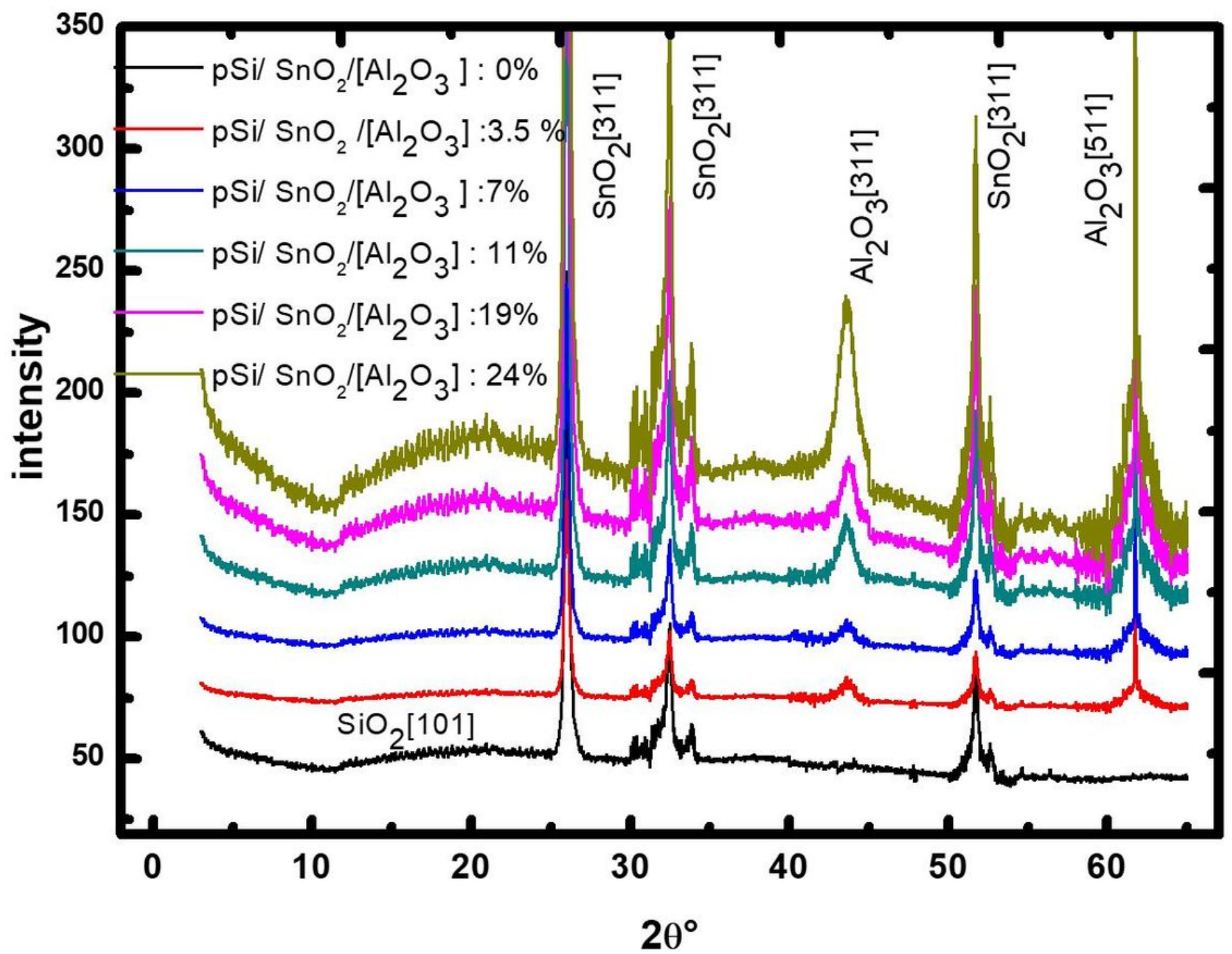

Figure 5

X-ray diffraction patterns $\mathrm{pSi} / \mathrm{SnO} 2$ coated with $\mathrm{Al} 2 \mathrm{O} 3$ at different concentration.

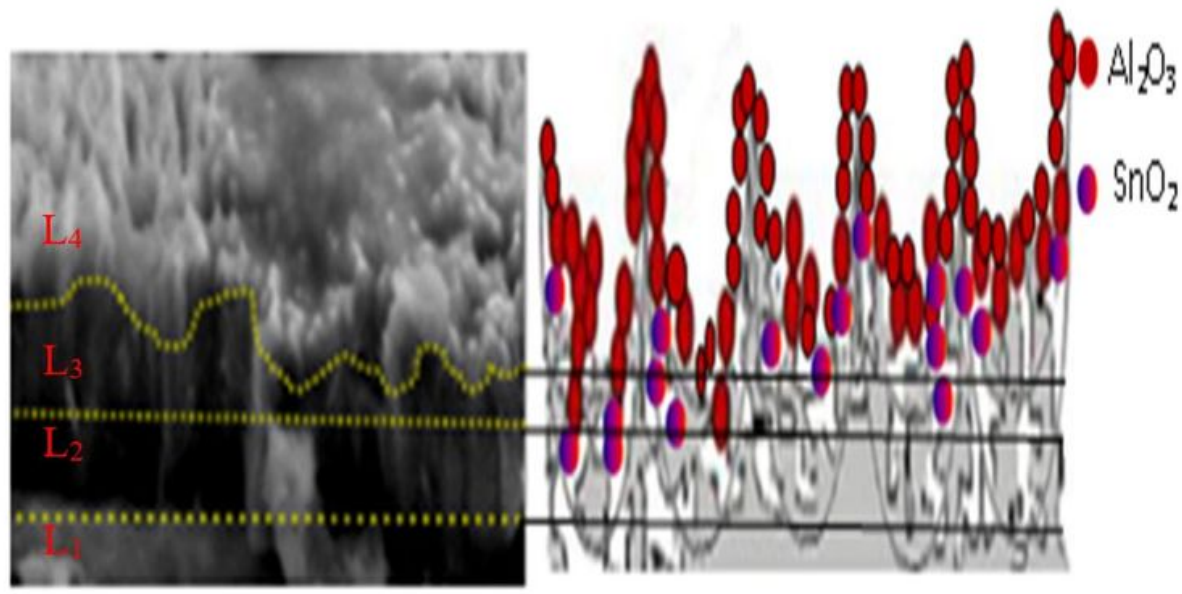

$\mathrm{L}_{4}: \mathrm{Si}(\mathbf{1 9 \%})$, Void (28\%), $\mathrm{SnO}_{2}$ $(20 \%), \mathrm{Al}_{2} \mathrm{O}_{3}(33 \%)$.

$\mathrm{L}_{3}: \mathrm{Si}(\mathbf{5 5 \%})$,Void (20\%), $\mathrm{SnO}_{2}$ $(20 \%), \mathrm{Al}_{2} \mathrm{O}_{3}(5 \%)$.

$\mathrm{L}_{2}: \mathrm{Si}(82 \%)$, Void (15\%), $\mathrm{SnO}_{2}$ $(3 \%)$.

$\mathrm{L}_{1}: \mathrm{Si}(\mathbf{8 5} \%)$, Void (15\%).

Figure 6 
Multilayer model used to fit the pSi/SnO2/Al2O3 structure with different Al2O3 concentration.
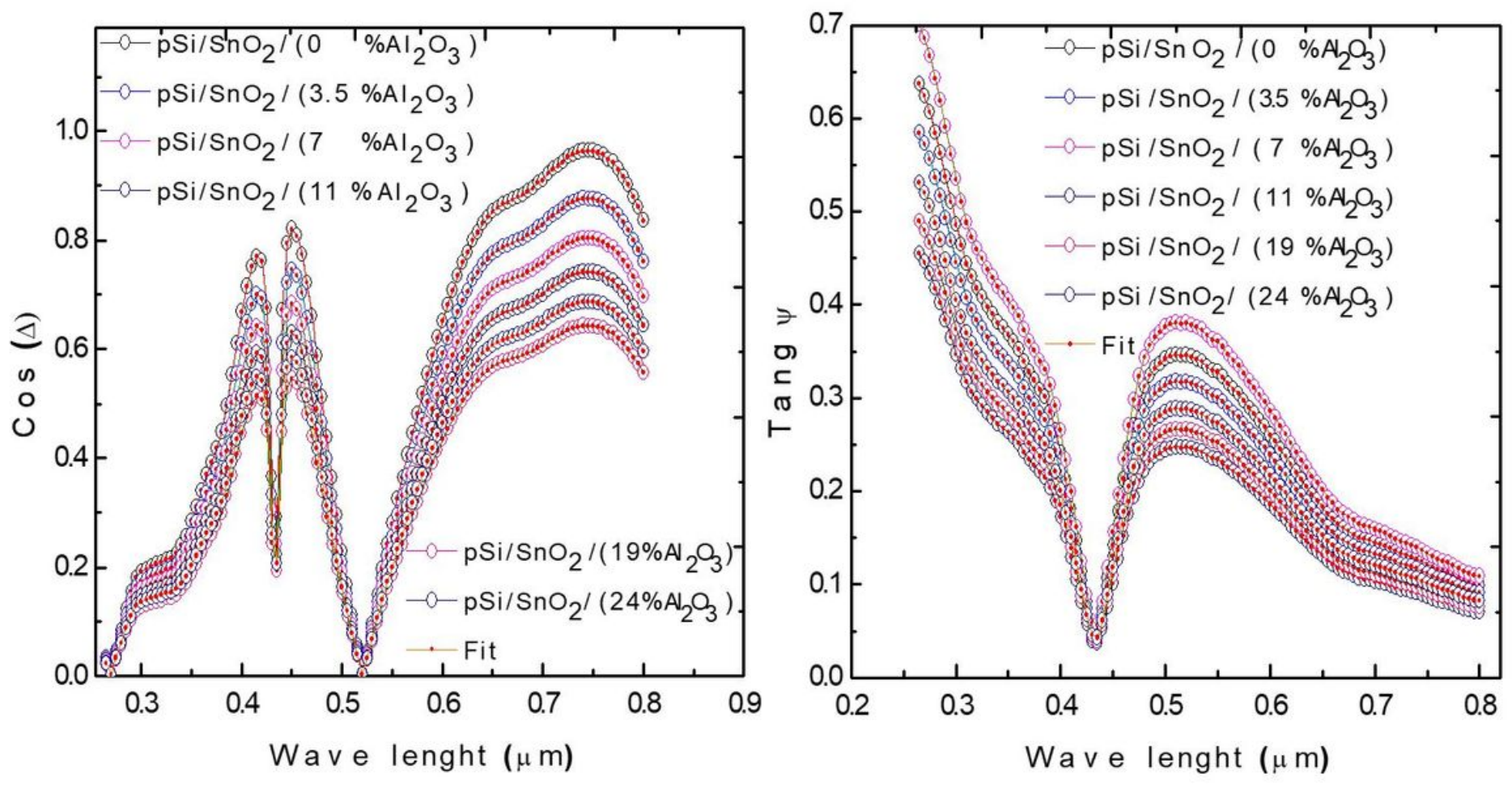

Figure 7

Experimental (Symbols) and fitted (Red-lines) SE data of pSi/ SnO2 coated with Al2O3 at different concentration.
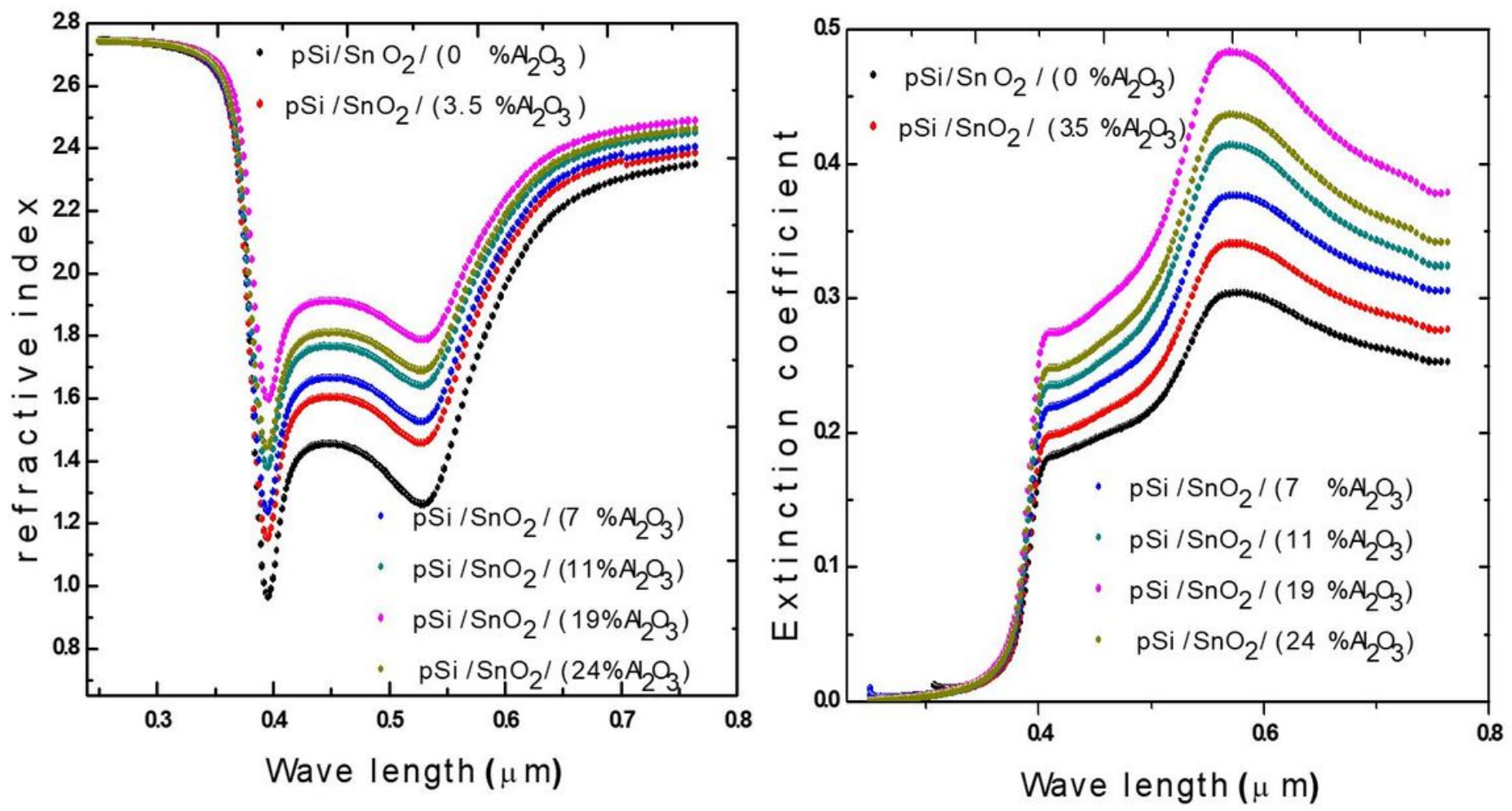

Figure 8 
Effect of Al203concentration on the refractive index $\mathrm{n}$ and the extinction coefficient $\mathrm{k}$ of $\mathrm{pSi} / \mathrm{SnO} 2 /$ $\mathrm{Al} 2 \mathrm{O} 3$ coated with $\mathrm{Al} 2 \mathrm{O} 3$ at different concentration.
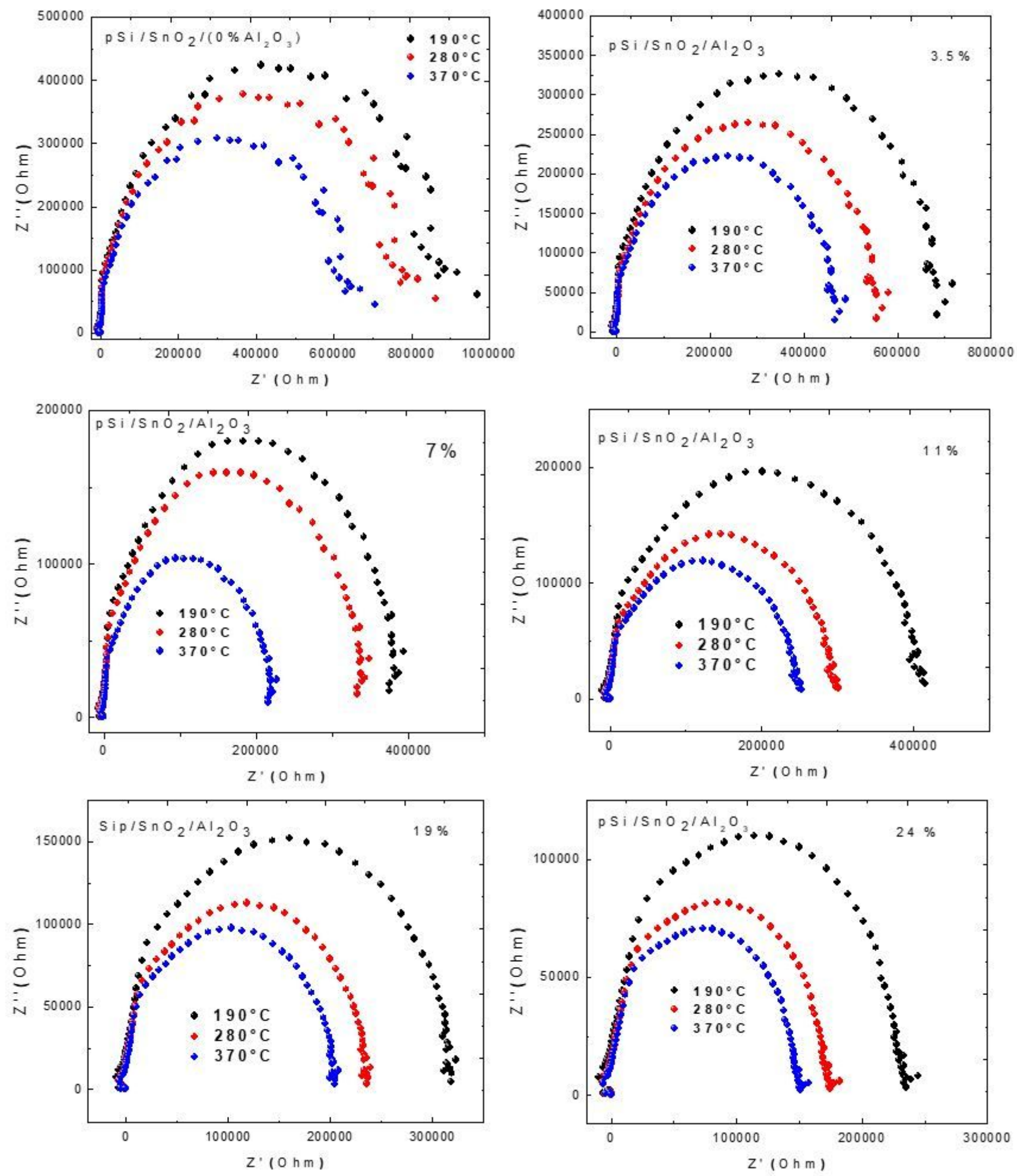

Figure 9

Complex impedance spectra of pSi/ SnO2/ Al2O3. 



Figure 10

Angular dependance of pSi/ SnO2/ Al2O3. 

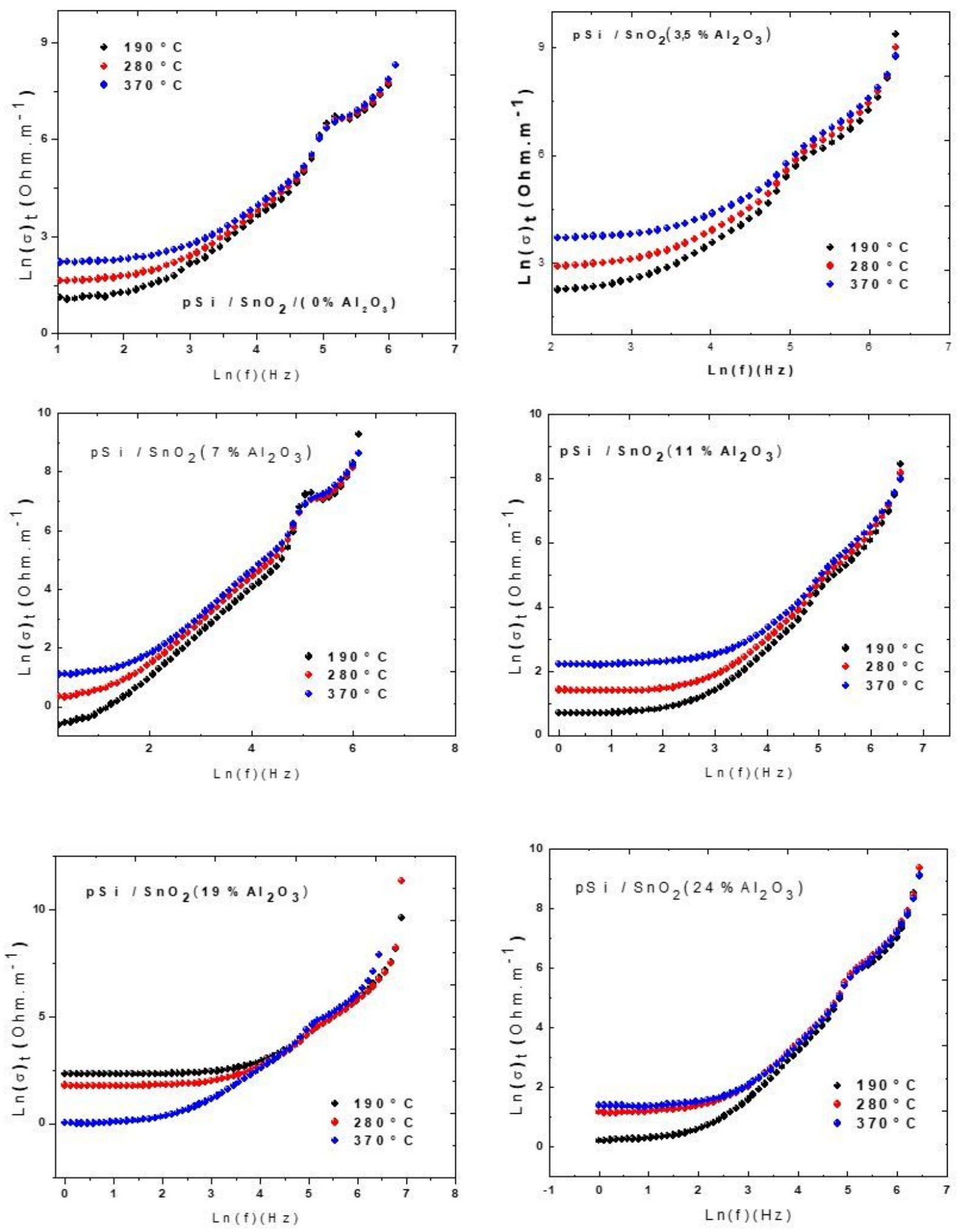

Figure 11

Angular dependance of ac conductivity of $\mathrm{pSi} / \mathrm{SnO2} / \mathrm{Al} 2 \mathrm{O} 3$ thin films. 

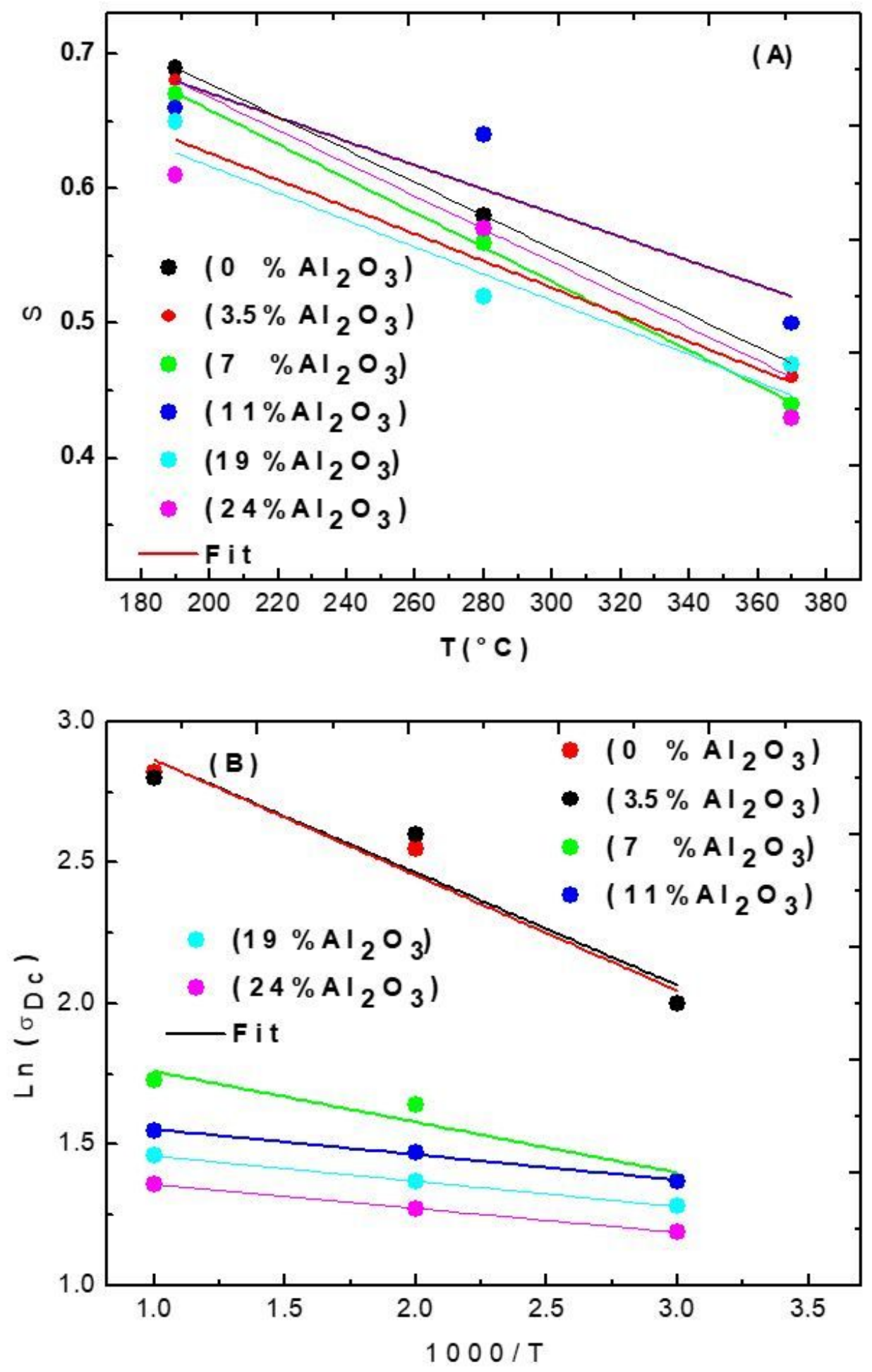

Figure 12

(a) Temperature dependence of the exponent S and (b) dc conductivity curve for pSi/ SnO2/ Al203. The dots are the experimental points and the solid line is the least-square straight line fit. 